Article

\title{
Optimal Operation of Hydropower Reservoirs under Climate Change: The Case of Tekeze Reservoir, Eastern Nile
}

\author{
Fikru Fentaw Abera ${ }^{1,2, *}$, Dereje Hailu Asfaw ${ }^{1}$, Agizew Nigussie Engida ${ }^{1}$ and \\ Assefa M. Melesse 2 (iD \\ 1 School of Civil and Environmental Engineering, Addis Ababa Institute of Technology (AAiT), \\ Addis Ababa 1000, Ethiopia; dereje_hasfaw@yahoo.com (D.H.A.); agiz70@yahoo.com (A.N.E.) \\ 2 Department of Earth and Environment, Florida International University, Miami, FL 33199, USA; \\ melessea@fiu.edu \\ * Correspondence: ffentawa@fiu.edu; Tel.: +1-973-424-3654
}

Received: 3 January 2018; Accepted: 27 February 2018; Published: 5 March 2018

\begin{abstract}
Optimal operation of reservoirs is very essential for water resource planning and management, but it is very challenging and complicated when dealing with climate change impacts. The objective of this paper was to assess existing and future hydropower operation at the Tekeze reservoir in the face of climate change. In this study, a calibrated and validated Soil and Water Assessment Tool (SWAT) was used to model runoff inflow into the Tekeze hydropower reservoir under present and future climate scenarios. Inflow to the reservoir was simulated using hydro-climatic data from an ensemble of downscaled climate data based on the Coordinated Regional climate Downscaling Experiment over African domain (CORDEX-Africa) with Coupled Intercomparison Project Phase 5 (CMIP5) simulations under Representative Concentration Pathway (RCP) 4.5 and RCP8.5 climate scenarios. Observed and projected inflows to Tekeze hydropower reservoir were used as input to the US Army Corps of Engineer's Reservoir Evaluation System Perspective Reservoir Model (HEC-ResPRM), a reservoir operation model, to optimize hydropower reservoir release, storage and pool level. Results indicated that climate change has a clear impact on reservoir inflow and showed increase in annual and monthly inflow into the reservoir except in dry months from May to June under RCP4.5 and RCP8.5 climate scenarios. HEC-ResPRM optimal operation results showed an increase in Tekeze reservoir power storage potential up to $25 \%$ and $30 \%$ under RCP4.5 and RCP8.5 climate scenarios, respectively. This implies that Tekeze hydropower production will be affected by climate change. This analysis can be used by water resources planners and mangers to develop reservoir operation techniques considering climate change impact to increase power production.
\end{abstract}

Keywords: reservoir operation; optimization; SWAT; HEC-ResPRM; climate change; CORDEX-Africa; Tekeze basin

\section{Introduction}

Water resources reservoirs are important tools for integrated water resources development and management [1,2], but nowadays their operation and management is challenging due to various factors [3,4]. The reservoir operates to supply water for municipal consumption, hydropower production, irrigation and industrial needs, flood control, recreation, navigation or ecological requirements. Currently, due to water crisis the global freshwater supply to meet the needs of the different sectors is falling short [5-7]. Factors that contribute to this include population growth, urbanization, climate change, land use change, land degradation and poor water resources management $[8,9]$. Hence, to alleviate these problems and meet the freshwater and energy demand of communities, it will necessitate optimal operation of water resources reservoirs [10,11]. 
Various researchers studied the reservoir operation throughout the world to get optimum level of release and optimal volumes of storage considering inflows and needs [12-15]. Most research conducted in the reservoir operations have specific objectives like hydropower [12,14,15], flood control [13], irrigation [3] and environmental [16].

Water resources infrastructures have been designed and managed historically but these designs gave little attention to the effect of climate change and non-stationarity in hydrologic variables [17]. Evidence suggests that these hydrologic variables used for water resources planning and management previously assumed stationarity in time have changed by anthropogenic activities [18]. The increase in temperature, changes in precipitation and evapotranspiration rates due to climate change alters global hydrologic cycle [19]. The streamflow affected by intensity and frequency of precipitation leads to increase the intensity of floods and droughts. These changes affect water resources at local and regional levels [20]. The hydrological processes and water availability affected by a change in the patterns of precipitation and temperature impacts agriculture, industry, communities, hydropower and aquatic life [21]. Climate change impact on fresh water resources may change the mean annual streamflow, shift seasonal flows, increases floods and droughts and changes in sediment fluxes which affects reservoir operation [22-24].

Many researchers in different parts of the world have studied the impacts of climate variability and change on shifts in hydrological regimes and water resources (e.g., [25-28]). These studies assessed the current and future water resources availability and rainfall variability across the globe to support appropriate water resources planning and management. Different studies showed that Africa is highly vulnerable to climate change [29]. Climate change studies showed temperature increased and precipitation pattern changed throughout arid and semi-arid regions of Africa [30-32] and affected the hydrological processes that impacts reservoir operation. Most studies showed the impacts of climate change on African hydropower reservoirs [23,33-36]. Kim and Kaluarachchi [33] and Beyene et al. [34] projected that precipitation and temperature will be increased in the Nile River basin and have positive effect on hydropower production, but Yamba et al. [35] and Hamududu and Killingtveit [36] investigated that in the next 60 years hydropower production show a gradual reduction with large variability in the Zambezi River basin. In the Nile River basin, the rapidly growing hydropower based energy need, population growth, food insecurity and finite water resources will lead to competitions for water in the riparian countries and this will be aggravated by the climate change. Several studies have been conducted on the variability of precipitation and streamflow in the Nile River basin [37-41] that affects reservoir planning and management [3].

Most hydropower reservoir operators concern is existing hydrological variability without foreseeing climate change as a particular serious threat [23]. Hence reservoir operation need to incorporate plans to address hydrologic non-stationarity and uncertainty caused by climate change $[20,26,42,43]$. Due to this, ensembles of Global Circulation Models (GCMs), scenarios and regional climate models (RCMs) used as input to hydrological model to generate future streamflow $[44,45]$ that can be used as an input for reservoir operations.

Sedimentation may cause serious impacts on reservoir operation and functionality by reducing reservoir storage capacity and shortening reservoir useful life for human benefits. Studies showed that Northern part of the Tekeze basin watersheds are vulnerable to sedimentation and/or soil erosion problems for the sustainable use of small reservoirs developed for irrigated agriculture and Tekeze reservoir [46,47]. This reservoir sedimentation problem may lead serious reduction in reservoir storage capacity, causing future hydropower generation problems. However, rate of sedimentation of Tekeze reservoir still remains unpredicted. More and wide knowledge is still needed to better understand and solve the sediment problem, and hence may improve future reservoir operation. But the focus of this research is to study potential climate change impact on hydropower reservoir operation and management by not varying sedimentation level.

Nowadays, reservoir operation techniques become increasingly important and researchers still searching the best technique. Many authors proposed and reviewed various reservoir operation models 
and methods [4,48-51]. Labadie [50] extensively reviewed and evaluated various optimization methods and reported that no universally approved algorithm for all reservoir operations. Rani and Moreira [4] investigated that optimization models usually require simulation models for verifying and testing planned operating policies. Dam managers use simulation models more relaxed than optimization models as simulation models are easier to interpret, apply and present to non-professionals $[49,50]$. But Optimization models give reliable results. In recent years, to overcome these problems, a combination of simulation and optimization models applied in reservoir operation. In this research, US Army Corps of Engineer's Reservoir Evaluation System Perspective Reservoir Models (HEC-ResPRM), a combination of simulation and optimization model is used.

In this study, Tekeze hydropower reservoir was chosen due to: (1) Tekeze basin shows high rainfall variability [37,52] which affects reservoir inflow; (2) Tekeze hydropower reservoir not designed by considering hydrological non-stationarity and climate change; (3) the reservoir has not been optimally operated and sometimes not fully functional during dry periods. Therefore, the objective of this research are to (1) assess impact of climate change on reservoir inflow using Soil and Water Assessment Tool (SWAT) and recent Coordinated Regional climate Downscaling Experiment over African domain (CORDEX-Africa) RCMs under Representative Concentration Pathway (RCP)4.5 and RCP8.5 climate scenarios, and (2) apply HEC-ResPRM optimization model to get optimal release, reservoir level and storage for optimal power production including in the face of climate change.

\section{Material and Methods}

\subsection{Study Area}

Tekeze basin, a tributary of Tekeze-Setit-Atbera river part of Eastern Nile (Figure 1) is geographically located from $11^{\circ} 40^{\prime}$ to $15^{\circ} 12^{\prime} \mathrm{N}$ and $36^{\circ} 30^{\prime}$ to $39^{\circ} 50^{\prime} \mathrm{E}$. The surface area of the Tekeze reservoir watershed is $29,404 \mathrm{~km}^{2}$. This basin has high mountainous areas in its sources in the central Ethiopian highlands up to $4517 \mathrm{~m}$ and low land areas near Ethio-Sudan border as low as $800 \mathrm{~m}$ with varying climate depending on altitude change. The rainfall increases with altitude from $600 \mathrm{~mm}$ to $1200 \mathrm{~mm}$ but it is a reverse for temperature which decreases from $26^{\circ} \mathrm{C}$ to $10^{\circ} \mathrm{C}$. This basin has a mean annual inflow of 4.4 Billion cubic meters at Embamadre gauging station and annual potential evapotranspiration of $1778 \mathrm{~mm}$.

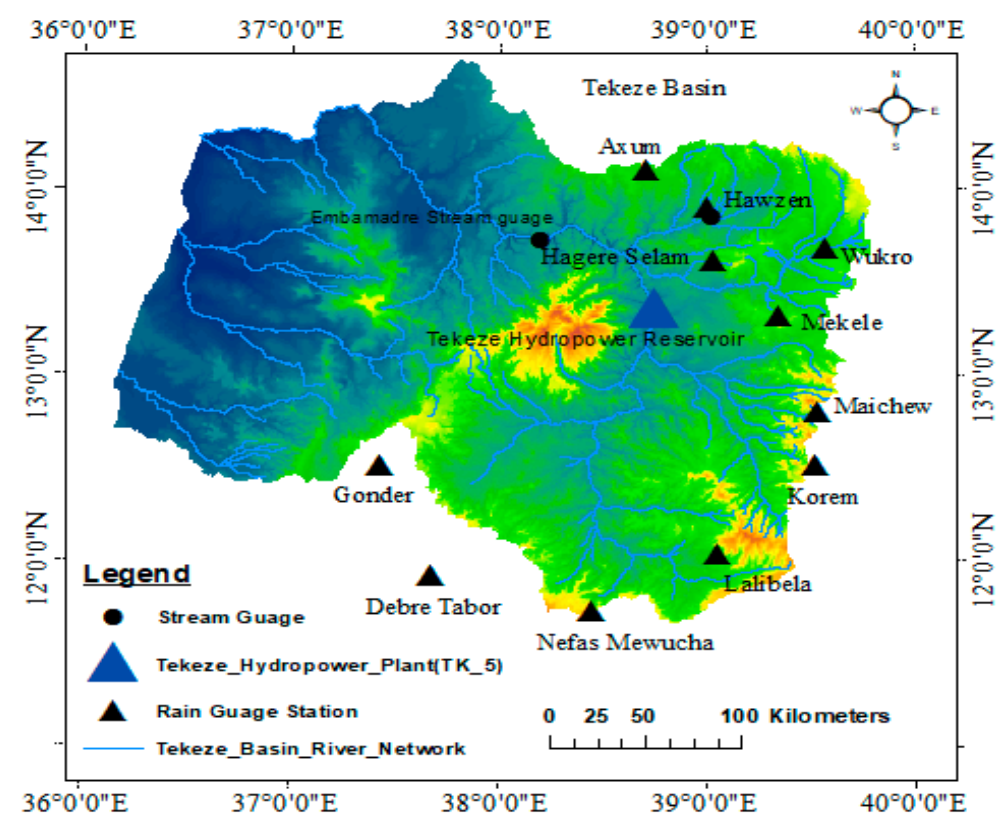

Figure 1. Location of Tekeze hydropower reservoir and weather stations. 
Tekeze basin has a large elevation drop from its sources to low land areas near Ethio-Sudan border and offers a significant hydropower potentials of $5960 \mathrm{GWh} /$ year. Tekeze single purpose hydropower reservoir located at $13^{\circ} 21^{\prime} \mathrm{N}$ and $38^{\circ} 45^{\prime} \mathrm{E}$ (Figure 1) is the second tallest double concrete arch dam in Africa next to Katse arch dam in Lesotho. The purpose of this reservoir is for hydropower production with total installed capacity of $300 \mathrm{MW}$ in four $75 \mathrm{MW}$ Francis turbines at underground power house. The reservoir has a total storage capacity of 9293 million cubic meters (MCM) of which 5293 MCM live storage at $1140 \mathrm{~m}$ above sea level (masl) and 4000 MCM below dead storage level (1096 masl). The reservoir also has $147 \mathrm{~km}^{2}$ surface areas at full supply level with mean annual inflow of $3750 \mathrm{MCM}$.

\subsection{Datasets Used}

\subsubsection{Historical and Future Hydrology}

In this research, four hydrological data periods were analyzed. These were the reservoir inflow data of: (1) observed and RCP scenarios historical records (1994-2008); (2) the near future period (2011-2040), middle future period (2041-2070) and the far future periods (2071-2100). SWAT simulates historical (past) and all future reservoir inflows using precipitation and temperature projections from ensemble outputs of CORDEX-Africa RCMs downscaled from different GCMs from Coupled Intercomparison Project Phase 5 (CMIP5) simulations available in $0.44^{\circ}$ resolution for Ethiopian domain under two recent representative concentration pathways (RCP4.5 and RCP8.5) climate scenarios. There are numerous weather stations in Tekeze basin. For this study, stations recording precipitation and temperature data that have long period of records with small data gaps were used. There are more than 20 streamflow gauged stations in the Tekeze basin but most of the stations are found in the small tributaries of Tekeze River which covers only small watershed areas. These stations, except Embamadre station, have large data gaps, short record periods and high amount of missing data. Observed streamflow at Embamadre station was collected from Ethiopian Ministry of Water, Irrigation and Electricity.

\subsubsection{CORDEX-Africa}

Currently, CORDEX-Africa initiated by World Climate Research Program (WCRP) provides an opportunity for the generation of high resolution regional climate projections over Africa that is used to assess future impacts of climate change at regional and local scales. In this study, results of CORDEX-Africa ensemble RCMs simulations for the past (1951-2005) and future (2006-2100) climate projections downscaled from different GCMs under RCP4.5 and RCP8.5 with spatial resolution of $0.44^{\circ}$ is used. CORDEX-Africa RCMs generate an ensemble of high resolution historical and future climate projections at regional scale by downscaling different GCMs forced by RCPs based on the Coupled Intercomparison Project Phase 5 (CMIP5) [32,53]. CORDEX-Africa climate projections use RCP4.5 and RCP8.5 climate scenarios.

RCPs are new climate change scenarios established by CMIP5 [54,55], which can depict a wide variety of possible future climate scenarios. The fifth Assessment Report (AR5) scientific literature selects one mitigation scenario (RCP2.6), two medium stabilization scenarios (RCP4.5 and RCP6.0) and one high emission scenario. RCP2.6 scenario sees emissions peak early, then fall shown to be technically feasible. But one of RCP2.6 scenario key assumptions is the full participation of all developed and developing countries in the world in the short run to reduce all the main emitters, which is not possible in actual cases. Due to this, we decided to choose one medium scenario (RCP4.5) and high scenario (RCP8.5) covering entire range of radiative forcing. RCPs represent pathways of radiative forcing, not linked with exclusive socio-economic assumption in contrary to Special Report on Emission Scenarios (SRES). Any single radiative forcing pathway can result from a diverse range of socio-economic and technological development scenarios. RCP4.5 is a mid-range scenario that stabilizes radiative forcing at $4.5 \mathrm{~W} / \mathrm{m}^{2}$ (approximately $650 \mathrm{ppm} \mathrm{CO}_{2}$-equivalent) in the year 2100 without exceeding this value, but this does not imply the climate system are stable $[53,56]$. Whereas RCP8.5 is upper bound of all RCP scenarios that stabilizes radiative forcing at $8.5 \mathrm{~W} / \mathrm{m}^{2}$ (greater than $1370 \mathrm{ppm} \mathrm{CO}$-equivalent) in the year $2100[53,57]$. 


\subsubsection{Reservoir Data}

HEC-ResPRM, a reservoir operation model, requires data like back ground map of the watershed, reservoir outlet capacities, elevation-area-storage curve, current outflow-energy relationship, power production and flow time series to perform optimal operations. These physical data were used to develop model constraints and allow the model to calculate penalties. All these data were collected from Ethiopian Electric Power Corporation and Ministry of Water, Irrigation and Electricity.

\subsection{Methods}

\subsubsection{Overview of SWAT}

Soil and Water Assessment Tool (SWAT) was used to produce inflow projections and assess climate change impact on the streamflow used as an input for reservoir operation. The details of SWAT shown in Neitsch et al. [58]. It is a semi-distributed continuous widely used hydrological model in the Eastern Nile basins $[59,60]$. Since the objective of the study was to examine streamflow response to climate change, the land phase of the hydrologic cycle simulated by SWAT is based on the water balance equation:

$$
\mathrm{SW}_{\mathrm{t}}=\mathrm{SW}_{\mathrm{o}}+\sum_{i=1}^{t}\left(\mathrm{R}_{\text {day }}-\mathrm{Q}_{\text {surf }}-\mathrm{E}_{\mathrm{a}}-\mathrm{W}_{\text {seep }}-\mathrm{Q}_{\mathrm{gw}}\right)
$$

in which $\mathrm{SW}_{\mathrm{t}}$ is the final soil water content $(\mathrm{mm}), \mathrm{SW}_{\mathrm{o}}$ is the initial soil water content on day $i(\mathrm{~mm})$, $t$ is the time (days), $\mathrm{R}_{\text {day }}$ is the amount of precipitation on day $i(\mathrm{~mm}), \mathrm{Q}_{\text {surf }}$ is the amount of surface runoff on day $i(\mathrm{~mm}), \mathrm{E}_{\mathrm{a}}$ is the amount of evapotranspiration on day $i(\mathrm{~mm}), \mathrm{W}_{\text {seep }}$ is the amount of water entering the vadose zone from the soil profile on day $i(\mathrm{~mm})$, and $\mathrm{Q}_{\mathrm{gw}}$ is the amount of return flow on day $i(\mathrm{~mm})$. Surface runoff volume was estimated using modified Soil Conservation Serves-Curve Number (SCS-CN) method.

In this study, SWAT was used together with the ArcSWAT interface, a geographic information system (GIS) based graphical user interface used to facilitate watershed delineation and initial parameterization. The SWAT model requires digital elevation model (DEM), land cover/land use information, soils and basic climate data. The land use/land cover data of the Tekeze basin includes agricultural land, shrub land (range grasses), mixed forests and pasture/grazing lands. SWAT subdivides the watershed in to hydrological response units (HRUs) with a homogeneous land use and soil properties based on topography and quantifies the relative impacts of soil, land use and climate change within each HRU. The $30 \mathrm{~m} \times 30 \mathrm{~m}$ DEM, soil properties, land use/land cover and streamflow data were all collected from Ethiopian Ministry of Water, Irrigation and Electricity. Meteorological data of precipitation and temperature (1994-2008) were collected from National Meteorological Service Agency. Sensitivity analysis was done using Latin Hypercube sampling based on One Factor at a Time (LH-OAT) inbuilt in SWAT to identify sensitive parameters that influence model simulations. The sensitive parameters of this study mainly affecting model calibration were curve number (CN-2), soil available water capacity (Sol-AWC), alpha base flow recession constant (ALPHA-BF), soil evaporation compensation factor (ESCO), threshold water depth required for return flow to occur (GWQMN) and saturated hydraulic conductivity (SOL_K). Model calibration adjusts such high sensitive parameters to optimize the agreement between observed and simulated streamflow values at Embamadre station in Tekeze basin. Model performance was assessed using Nash-Sutcliffe efficiency ( $\left.E_{N S}\right)$, coefficient of determination $\left(R^{2}\right)$ and percent of bias (PBIAS). Finally, the historical and future $\mathrm{RCP} 4.5$ and RCP8.5 projections of precipitation and temperature were used as input into the calibrated and validated SWAT model to assess the impact of climate change on reservoir inflow.

\subsubsection{HEC-ResPRM Optimization Model}

In this study, the US Army Corps of Engineer's Reservoir Evaluation System Perspective Reservoir Model (HEC-ResPRM), a reservoir system operations optimizations software package developed to 
assist planners, operators and managers with reservoir operation plan and decision making, was used. It addresses a reservoir system operation problem of optimal long-term allocation of available water. HEC-ResPRM is a combination of simulation and optimization model when Perspective Reservoir Model (PRM) is integrated in to HEC-RES modeling platform. It is an implementation of HEC-PRM shared with HEC-ResSim in a graphical user interface for creating, running, sorting and analyzing optimization runs. HEC-ResPRM uses HEC's data storage system (HEC-DSS) to store and retrieve of input and output time series data.

It is a monthly network flow programming model and gives optimal values of release and storage by minimizing penalty functions [61,62]. Network flow programming is computationally efficient form of linear programming. A network solver finds optimal flow for the entire network simultaneously based on the unit cost associated with flow along each arc. Optimization problem represented by the network with cost associated with flow as follows:

$$
\begin{gathered}
\text { Minimize : } \sum_{t}^{n} C_{t} Q_{t} \text { (For all nodes) } \\
\text { Subject to : } \sum Q_{t}-\sum a_{t} Q_{t}=0 \text { (For all nodes) } \\
L_{t} \leq Q_{t} \leq U_{t} \text { (For all arcs) }
\end{gathered}
$$

in which $n$ is total number of network arcs; $C_{t}$ is unit cost, weighting factor for flow along arc $t$; $Q_{t}$ is flow along arc $t ; a_{t}$ is multiplier (gain) for arc $t ; L_{t}$ is lower bound on flow along arc $t$; and $U_{t}$ is upper bound on flow along arc $t$. In this case, node represents a reservoir and river or channel junctions. Arcs represent inflow and outflow links in the reservoir system. Each arc has a minimum and maximum flow that it must carry in the reservoir system. The arcs (inflow and outflow links) may transfer water between two points in space (transferring water in channels) or in time (changing pool elevations in the reservoir). Also, flow is conserved in the reservoir (node). Equations (2) through (4) are special forms of linear programming problems solved using primal simplex method.

\section{Results and Discussions}

\subsection{Climate Projections}

Projected annual temperature and precipitation showed an increasing trend in 2020s, 2050s and 2080s over Tekeze basin under RCP4.5 and RCP8.5 climate scenarios. Projected mean annual temperature may increase up to $1.1{ }^{\circ} \mathrm{C}$ and $3.38^{\circ} \mathrm{C}$ under RCP4.5 and RCP8.5 scenarios, respectively in all future time periods. Similarly, mean annual precipitation may increase up to $45 \%$ under both scenarios for all future time periods. Figure 2 shows future change rates of temperature in both scenarios for all future time periods. Mean monthly temperature will increase under both scenarios in all time periods except the months of January and February which showed a slightly decreasing trend in 2020s. Figure 3 shows future percentage changes of monthly precipitation amounts for different projected periods under RCP4.5 and RCP8.5 climate change scenarios. For RCP8.5 scenarios, the months of March, April and May would exhibit a decrease in precipitation amount compared to the baseline period whereas RCP4.5 scenario presented an increasing trend. The months of October through February would show an increase in precipitation compared to reference period for bothscenarios and projected periods considered. 


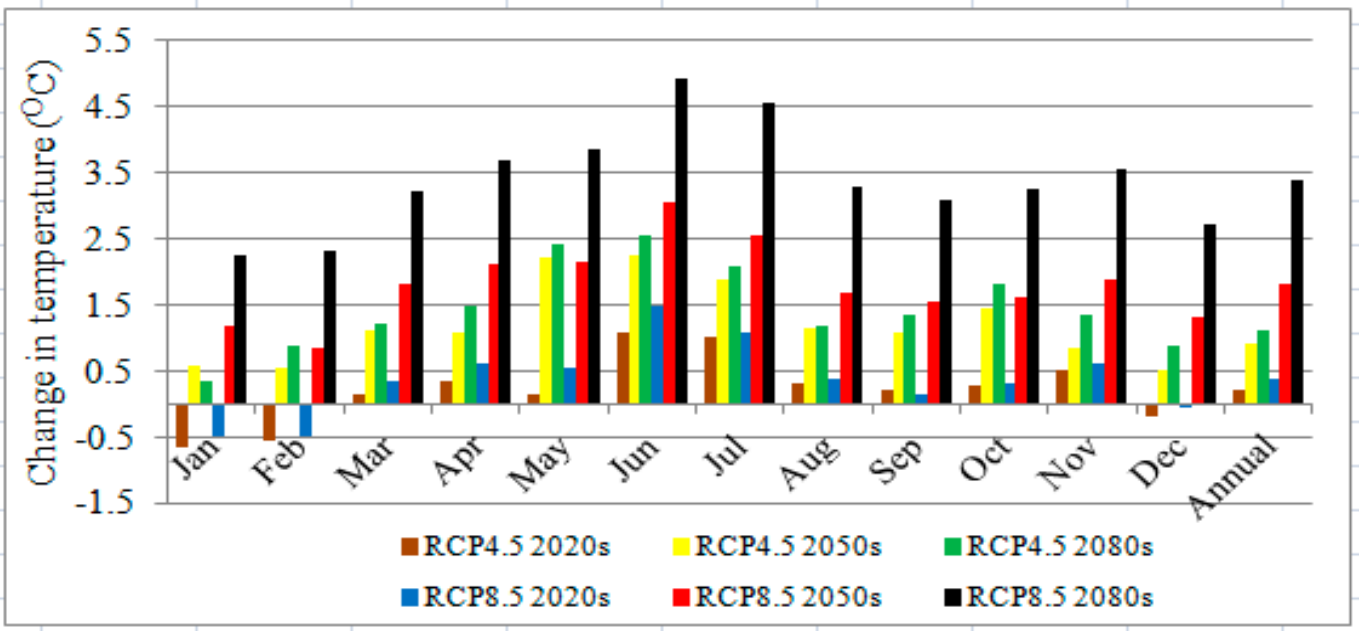

Figure 2. Rates of change of monthly mean temperature for the selected scenarios and projected periods.

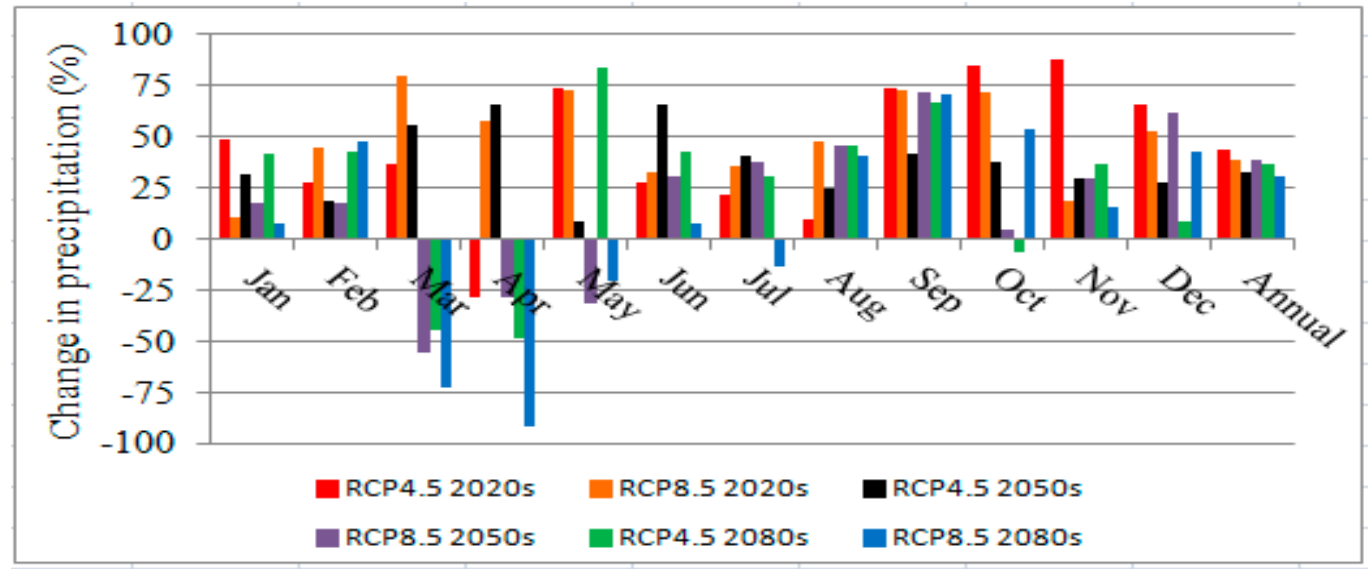

Figure 3. Change of monthly precipitation amount for the selected scenarios and projected periods.

\subsection{Impacts of Climate Change on Streamflow}

Impact of climate change on the streamflow at Embamadre station downstream of the reservoir was analyzed. Observed streamflow data from a period 1994-2002 was used for model calibration and from 2003-2008 was used for validation. Results in Figure 4 show that SWAT successfully simulated annual and monthly streamflow with a reasonable accuracy. The monthly result showed a good performance of SWAT, which indicated by the value of Nash-Sutcliffe efficiency ( $\left.E_{N S}\right) 0.70$ for calibration and 0.79 for validation and the coefficient of determination $\left(R^{2}\right) 0.73$ for calibration and 0.80 for validation. Similarly, percent of bias (PBIAS) value of $0.53 \%$ during calibration and $0.45 \%$ in validation periods showed good fit between observed and simulated streamflow.

Hence, the calibrated and validated SWAT forced to run for historical and future climate scenarios to generate future streamflow for both RCP4.5 and RCP8.5 climate scenarios. The effect of climate change on annual and monthly streamflow was also investigated as a percentage change with respect to the baseline period (1994-2008) under the two scenarios in three time periods 2020s (2011-2040), 2050s (2041-2070) and 2080s (2071-2100).

Figure 5 showed the percentage change of annual and monthly streamflow for both climate scenarios and the three time periods. Mean annual streamflow showed an increasing trend for both RCP4.5 and RCP8.5 for all time periods. Under RCP4.5, the mean annual percentage change of streamflow will increase by $49 \%, 39 \%$ and $47 \%$ in the 2020s, 2050s and 2080s, respectively. Similarly, for 
RCP8.5, the mean annual percentage change of streamflow increases to $22 \%, 19 \%$ and $2 \%$ in the 2020 s, 2050s and 2080s, respectively.

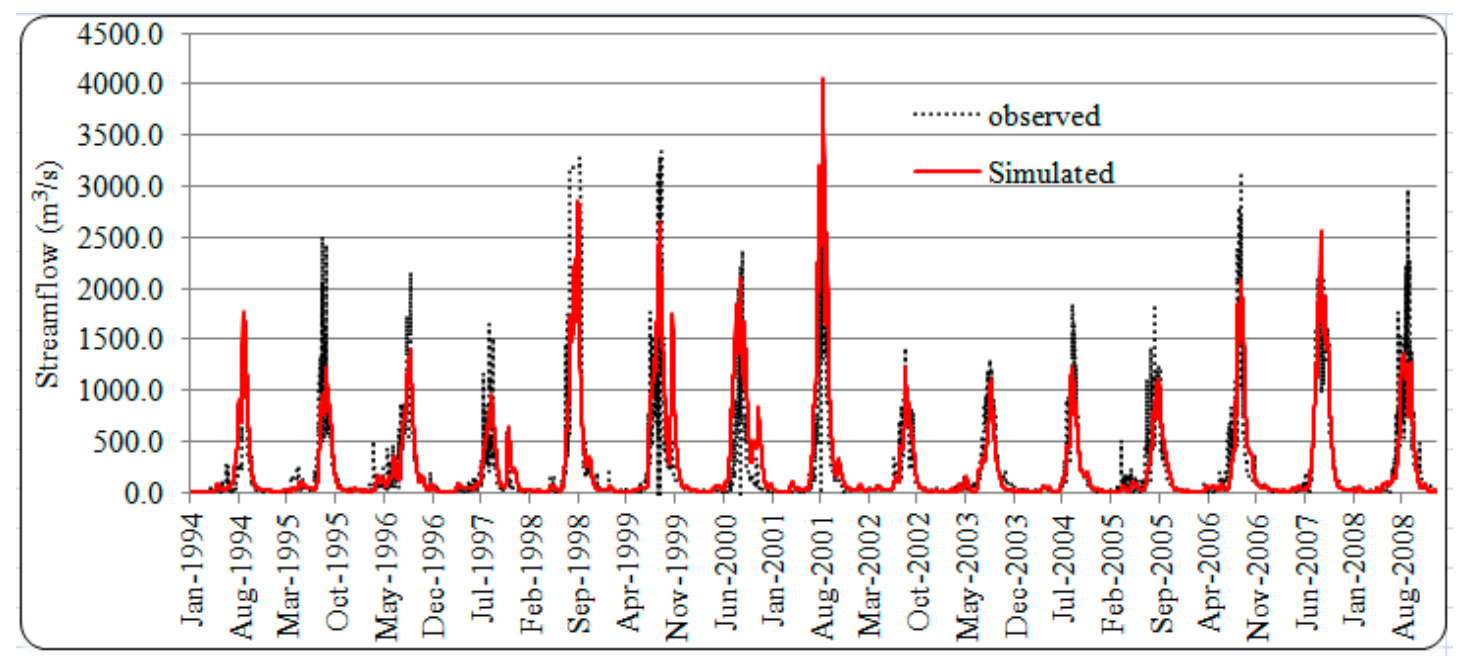

Figure 4. Observed and SWAT simulated monthly stream flow at Embamadre station.

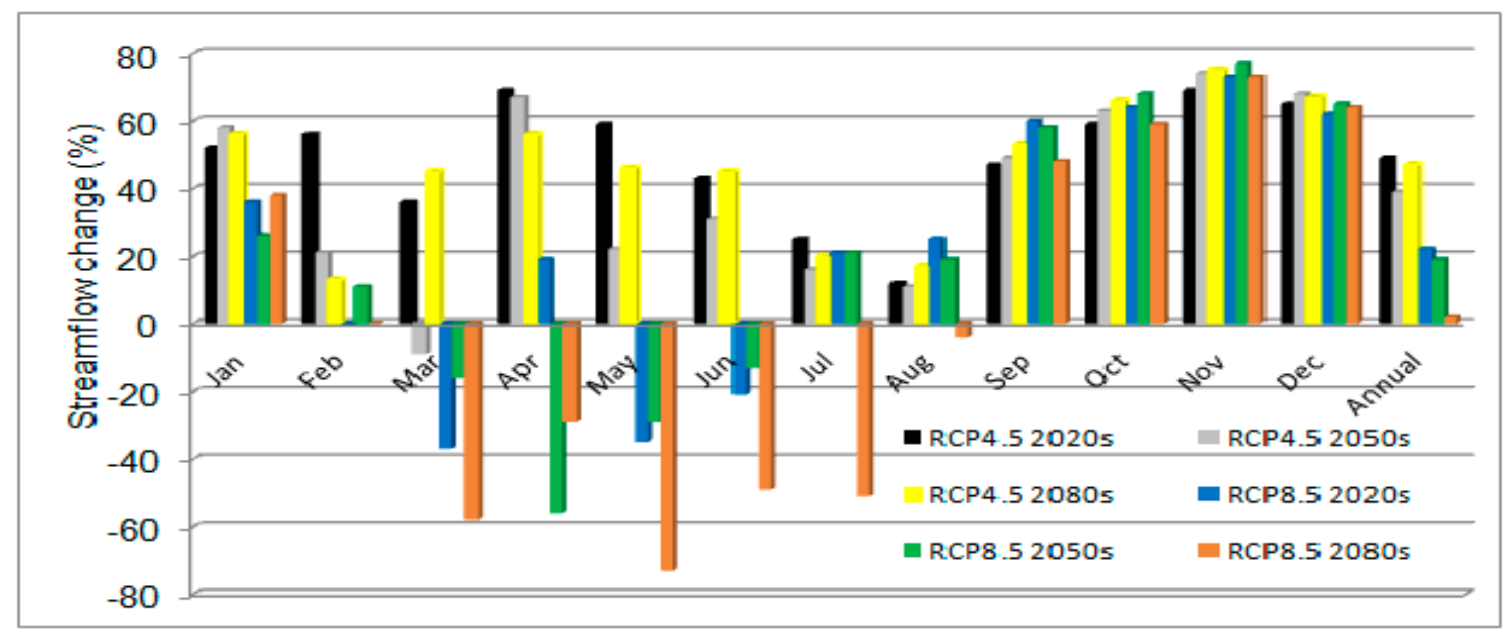

Figure 5. Mean monthly and annual streamflow changes under RCP4.5 and RCP8.5 climate scenarios.

The monthly streamflow change shows a mix of positive and negative trends. Under RCP4.5 climate scenario, change in average monthly streamflow ranges from 12 to $69 \%$ in 2020 s and 13 to $67 \%$ in 2080s but in 2050s streamflow change shows mixed trend that decreases in March to May by up to $9 \%$ and increases on other months up to $39 \%$. Mean monthly percentage change of streamflow under RCP8.5 climate scenario showed mixed trends in all time periods. Under RCP8.5, the mean monthly streamflow changes from -37 to $64 \%,-29$ to $68 \%$ and -49 to $64 \%$ in 2020s, 2050s and 2080s, respectively. Individual month's trend showed that there was an increasing trend from August to February and a decreasing trend from March to July. Therefore, climate change will have a clear impact on the future streamflow an input of reservoir power production in Tekeze basin.

The changes and variability of monthly (inter-annual) streamflow will be much greater than the annual streamflow changes in both scenarios in all time periods. This result showed that it is important for the hydropower reservoir planners and managers to consider, the monthly streamflow variability and changes for future planning and operation of reservoirs.

The total mean annual historical (past) and future Tekeze hydropower reservoir inflow $\left(\mathrm{m}^{3} / \mathrm{s}\right)$ trends under RCP4.5 and RCP8.5 climate scenarios for all time periods are shown in Figure 6. 


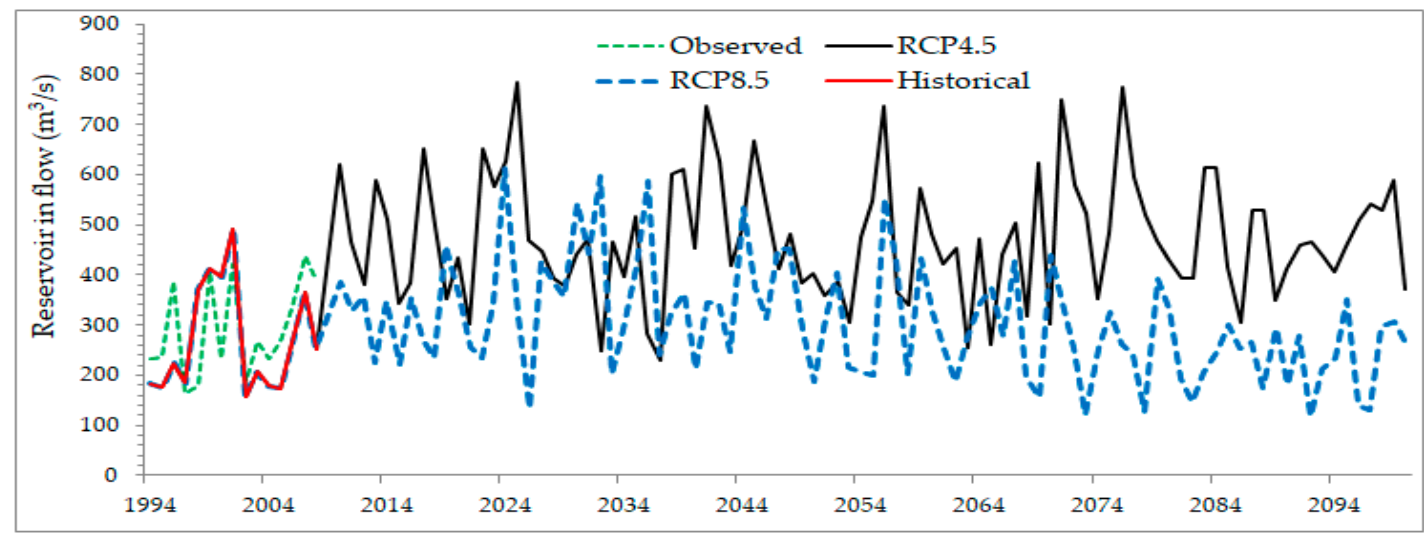

Figure 6. Annual Tekeze hydropower reservoir inflow trend for future time periods.

\subsection{Current Reservoir Operation}

HEC-ResPRM optimization model run under current baseline condition (2009-2017). This model optimized the current Tekeze hydropower reservoir operation. The current optimized value (Table 1) of HEC-ResPRM optimization model showed an increase in reservoir storage compared to current actual hydropower reservoir operation status. It is also indicated that the mean annual reservoir pool level increased up to $7.87 \mathrm{~m}$ (Table 2) that will store more water to produce power throughout the year. It contradicts the current actual Tekeze hydropower reservoir operation which produces insufficient power even very little or no power production during dry months. This implies that Tekeze hydropower reservoir was not optimally operated till now. The reservoir storage dropped to the minimum operating level and sometimes dries in the non-rainy months. Therefore, the current actual reservoir operation is not effective and should consider different well tested reservoir operation techniques under a changing climate.

Table 1. Mean annual optimized power storage under climate change scenarios.

\begin{tabular}{ccccc}
\hline Periods & \multicolumn{2}{c}{$\begin{array}{c}\text { Optimized Reservoir } \\
\text { Storage }\end{array}$} & \multicolumn{2}{c}{$\begin{array}{c}\text { Change in Optimized } \\
\text { Reservoir Storage (\%) }\end{array}$} \\
\hline & RCP4.5 & RCP8.5 & RCP4.5 & RCP8.5 \\
Current optimized & & 6639 & & 24.0 \\
2020s & 6688 & 6880 & 25.0 & 28.5 \\
2050s & 6669 & 6903 & 24.6 & 29.0 \\
2080s & 6665 & 6958 & 24.5 & 30.0 \\
\hline
\end{tabular}

Table 2. Mean annual optimized pool level variation under RCP4.5 and RCP8.5 climate scenarios in three future time periods.

\begin{tabular}{ccccc}
\hline \multirow{2}{*}{ Time Periods } & \multicolumn{2}{c}{ Optimized Pool Level (masl) } & \multicolumn{2}{c}{ Pool Level Change (m) } \\
\cline { 2 - 6 } & RCP4.5 & RCP8.5 & RCP4.5 & RCP8.5 \\
\hline Current optimized & \multicolumn{2}{c}{1120.48} & \multicolumn{2}{c}{7.87} \\
2020s & 1121.06 & 1123.27 & 8.45 & 10.66 \\
2050s & 1120.87 & 1123.37 & 8.26 & 10.76 \\
2080s & 1120.89 & 1123.85 & 8.28 & 11.24 \\
\hline
\end{tabular}

\subsection{Reservoir Operation under Climate Change}

The future reservoir inflows generated by SWAT under RCP4.5 and RCP8.5 climate scenarios in three time periods 2020s (2011-2040), 2050s (2041-2070) and 2080s (2071-2100) with other reservoir data 
were used to run optimization model to get projected optimal reservoir outflow (release), storage and pool level results.

\subsubsection{Projected Reservoir Inflow and Outflow}

Climate change impacted inflow and outflow (release) hydrograph of Tekeze hydropower reservoir considered in this study are shown in Figure 7a,b. According to the inflow projections based on ensembles of CORDEX-Africa RCM climate model simulations, total inflows to Tekeze hydropower reservoir expected to increase under RCP4.5 and RCP8.5 climate scenarios for all future time periods. Figure 7a,b show that total monthly inflow under RCP4.5 is greater than the total monthly inflow projected under RCP8.5 climate scenarios. However, under RCP4.5 climate scenario, the reservoir inflow projections exhibit high fluctuations inter-annually as compared to RCP8.5 climate scenario and observed historical values. The highest inflow volumes under RCP4.5 were concentrated in the rainy months that spilled easily and affect the dry period reservoir storage level and or release.

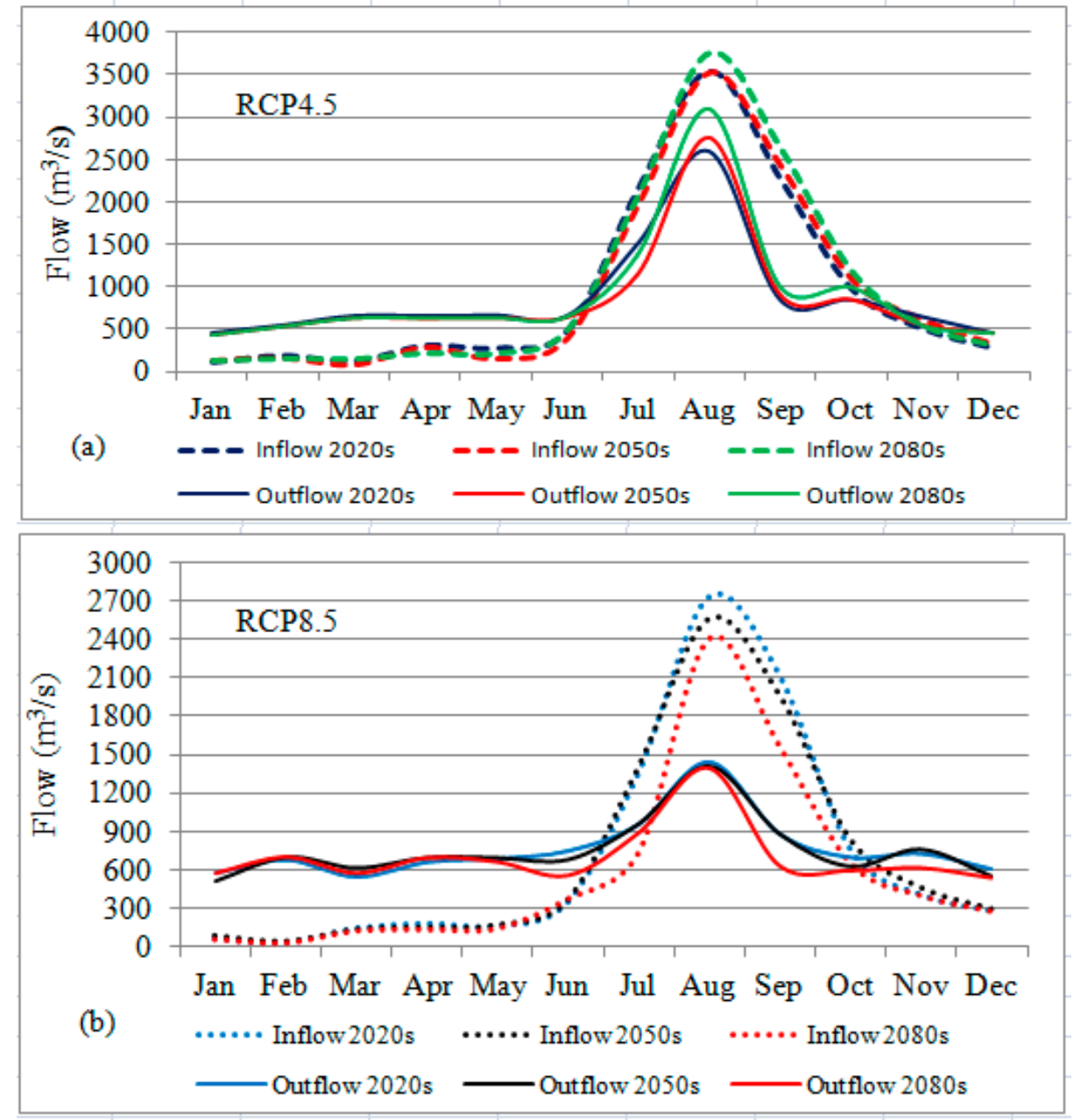

Figure 7. Mean monthly reservoir inflow and optimized outflow (release) for future time periods under: (a) RCP4.5 climate scenario; (b) RCP8.5 climate scenario.

There would be an increase in excess reservoir inflow during the rainy months of August through October under both RCP4.5 and RCP8.5 climate scenarios in all time periods. This increased spillage of available water inflow occurs because of the effect of climate change that increased the hydropower reservoir inflow under RCP4.5 and RCP8.5 future climate scenarios. According to the latest climate simulations, the overall inflow volume is predicted to be higher during rainy months and provided 
that the reservoir lack sufficient storage capacity to accommodate these high flows. As a result, Tekeze hydropower reservoir forced to spill water without generating hydropower. This indicates that the increased in overall reservoir inflow volume does not necessarily be advantageous to produce more power. Therefore, decision need to be taken on the amount of water to be released and or stored now and retained for future considering the variations in inflow and demands.

In this study, the reservoir outflow (release) was obtained by HEC-ResPRM optimization model under RCP4.5 and RCP8.5 climate scenarios for 2020s, 2050s and 2080s time periods. In all future time periods (Figure 7a,b) under the two climate scenarios, the reservoir release will be increased to produce more power due to an increased future reservoir inflow and optimum water storage using optimization model. Under RCP4.5 climate scenario average monthly reservoir outflow varies from 353 to $2590 \mathrm{~m}^{3} / \mathrm{s}$ in 2020s, 435 to $2757 \mathrm{~m}^{3} / \mathrm{s}$ in $2050 \mathrm{~s}$ and 442 to $3090 \mathrm{~m}^{3} / \mathrm{s}$ in 2080s. Similarly, average monthly reservoir outflow varies from 538 to $1445 \mathrm{~m}^{3} / \mathrm{s}$ in 2020s, 514 to $1412 \mathrm{~m}^{3} / \mathrm{s}$ in 2050s and 577 to $1396 \mathrm{~m}^{3} / \mathrm{s}$ in 2080s under RCP8.5 scenario. In both scenarios, the minimum and maximum outflow value occurred during dry and wet periods, respectively. In all time periods, the optimum reservoir outflows (releases) under RCP8.5 climate scenario for the dry months of November through February were greater than the optimum releases under RCP4.5 climate scenario. These changes show that under RCP8.5, the optimized reservoir stored more water in wet months for dry period release and projected higher storage level compared to RCP4.5 climate scenario.

\subsubsection{Optimum Reservoir Power Storage under Climate Change}

HEC-ResPRM optimized result showed an increase in projected mean annual Tekeze hydropower reservoir storage under RCP4.5 and RCP8.5 climate scenarios. This increase was projected for three future time periods (Table 1) and the projected optimum stored water varies from 24 to $25 \%$ (RCP4.5) and 28.5 to $30 \%$ (RCP8.5).

HEC-ResPRM model result under both scenarios in current and all future time periods showed a minimum and maximum reservoir storage periods (Figure 8). Tekeze reservoir reached at maximum storage (reservoir filled) in September and stayed somewhat constant optimum storage up to November. During August to September, main rainy months, the reservoir is filled and optimization model keeps the maximum storage up to November. The reservoir storage tends to slightly be decreased starting from end of November until the beginning of February. After February, the reservoir storage decreased down to the optimization model capacity to store energy at a minimum flow and reached a minimum storage level in June to prepare and capture inflows in the wet main rainy months. In all future months, there will be a stored water to produce power which is always greater than the current optimized value.

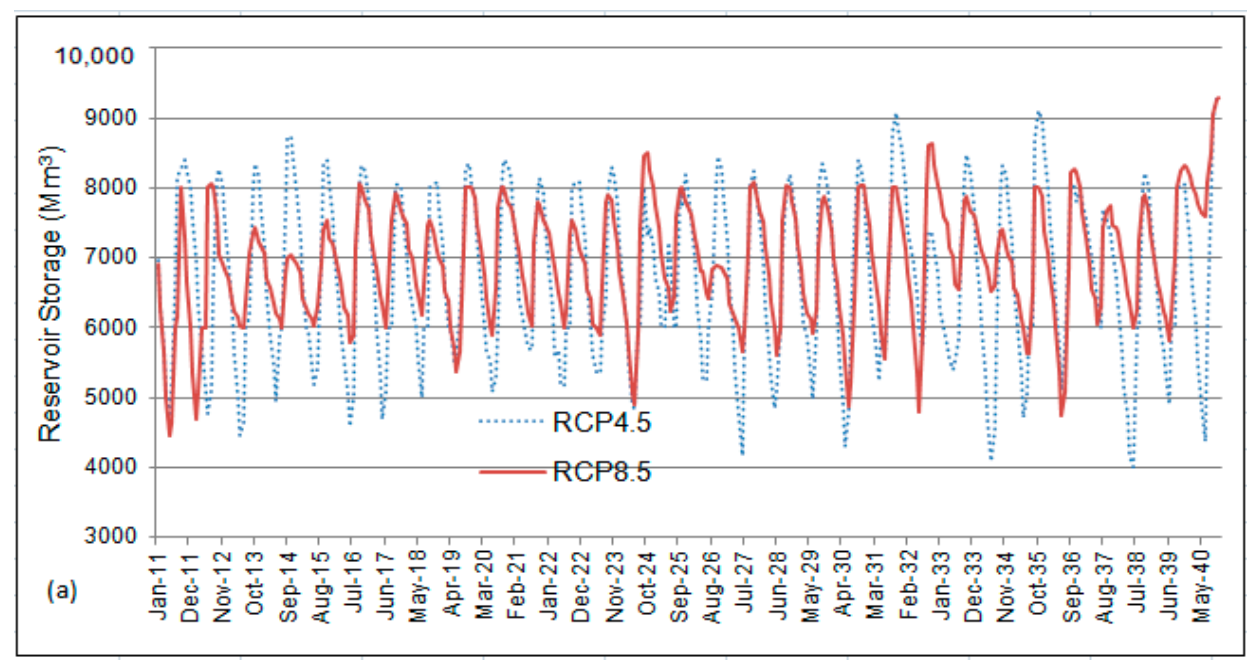

Figure 8. Cont. 

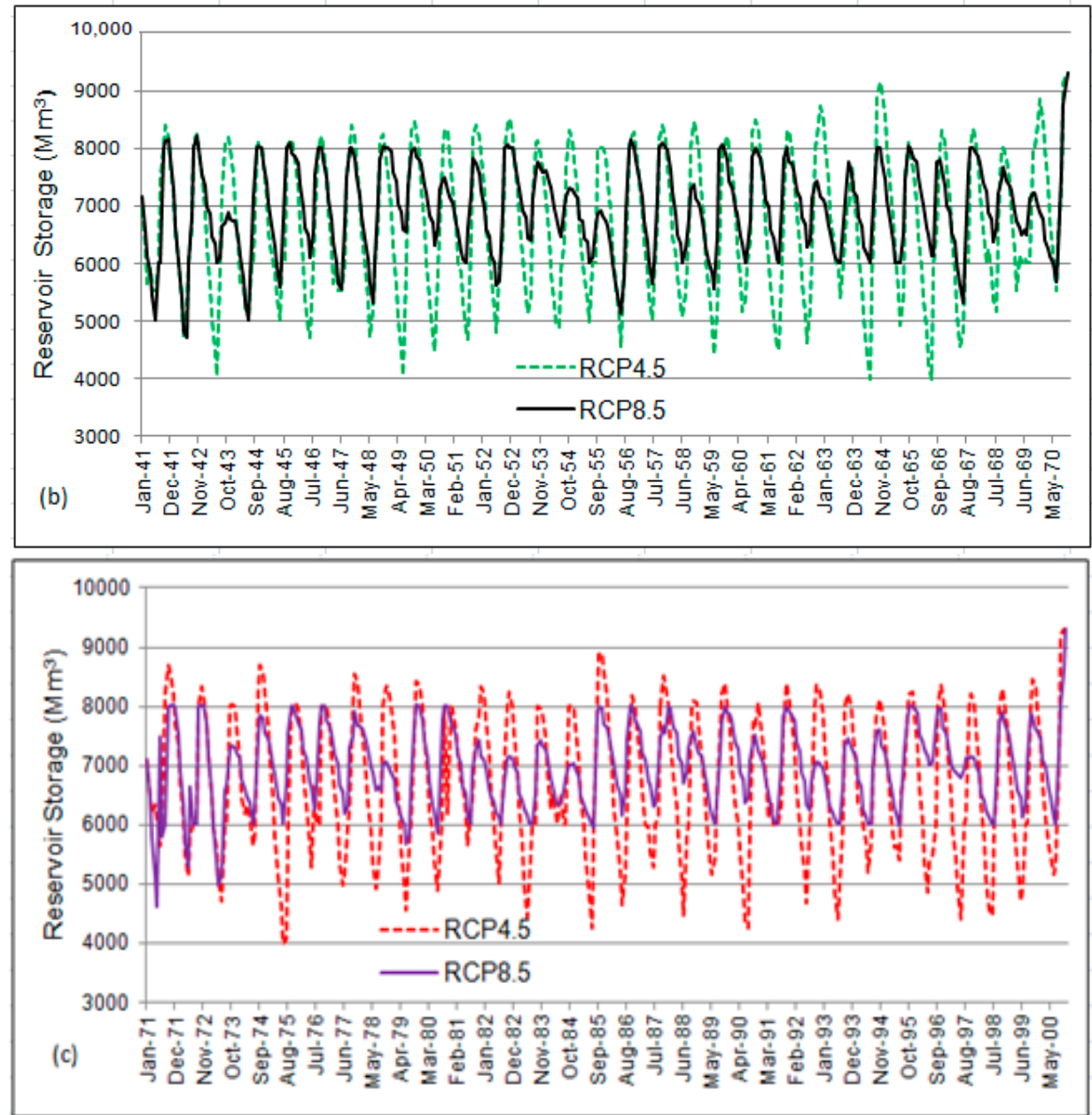

Figure 8. Monthly optimized reservoir storage variations under RCP4.5 and RCP8.5 climate scenarios for: (a) 2020s; (b) 2050s; (c) 2080s.

Figure 8 shows that more power is stored in both scenarios for the next 90 years as compared to current actual and current optimized value. The change in maximum optimum storage increased will be occurred in January and varies from 1693.4 to $1800.8 \mathrm{Mm}^{3}$ under RCP4.5 scenario and from 1731.9 to $1851.1 \mathrm{Mm}^{3}$ under RCP8.5 scenario in all time periods. The minimum optimal storage change increased will occur in July and varies from 392.2 to $424.7 \mathrm{Mm}^{3}$ under RCP4.5 scenario and 803.6 to $956.6 \mathrm{Mm}^{3}$ under RCP8.5 scenario in all time periods. This is due to climate change impact on the reservoir inflow and the capacity of the optimization model to operate the reservoir optimally. HEC-ResPRM optimization of future projections tends to make much greater seasonal use of reservoir storage than the current actual operations.

The monthly optimum stored water increases in all months for future time periods under both RCP scenarios as compared to the baseline period (base line varies from 4400 to $6500 \mathrm{Mm}^{3}$ ). Optimized monthly reservoir storage variations are shown in Figure 8. The mean monthly optimum reservoir storage in the future time periods varies for RCP4.5 from 5100 to $8300 \mathrm{Mm}^{3}$ in 2020s, 4700 to $8050 \mathrm{Mm}^{3}$ in 2050s and 5000 to $8100 \mathrm{Mm}^{3}$ in 2080s. It also varies for RCP8.5 from 4900 to $8100 \mathrm{Mm}^{3}$ in 2020s, 4850 to $8020 \mathrm{Mm}^{3}$ in 2080s and 750 to $7900 \mathrm{Mm}^{3}$ in 2080s.

\subsubsection{Optimum Reservoir Pool Level (Elevation) under Climate Change}

HEC-ResPRM optimization result indicates that Tekeze hydropower reservoir pool level will be increased under RCP4.5 and RCP8.5 scenarios in all time periods. This comparison made with 
the current mean annual reservoir operation pool level of 1112.61 masl from 2009-2017. In the three projected time periods, optimal pool level (Table 2) change varies from 8.26 to $8.45 \mathrm{~m}$ under RCP4.5 and 10.66-11.24 $\mathrm{m}$ under RCP8.5 climate scenarios. This is large elevation difference that will store more water in the rainy months for the dry season power production. The optimized pool levels under both scenarios in all time periods are larger than the current optimized pool level. This is due to the impact of climate change and hydrological non-stationarity on reservoir operation. The reservoir storage pool level change in RCP4.5 scenario is lower than RCP8.5 scenario due to increase in each year individual month's fluctuations in RCP4.5 scenarios because of future inflow variability that reduced the mean annual reservoir water storage level.

The Tekeze hydropower reservoir operational level is changing continually due to inflows occurred and releases are made to produce power. The start of dead storage level at 1096 masl (minimum live storage level) has been assumed for power production. Figure 9 shows the optimal reservoir pool level of Tekeze hydropower reservoir generated by HEC-ResPRM optimization model. These optimal pool level results have a similar pattern with the optimal reservoir storage variations and may be considered as rule curves for optimal operation of Tekeze hydropower reservoir under a given scenario and time period. The reservoir pool level stayed at high level every year from August to November when reservoirs filled during the rainy months of August through September. The drop of pool level in June caused due to optimization model constraint reservoir not emptied and a transition zone when the drawdown ends and reservoir refill start.
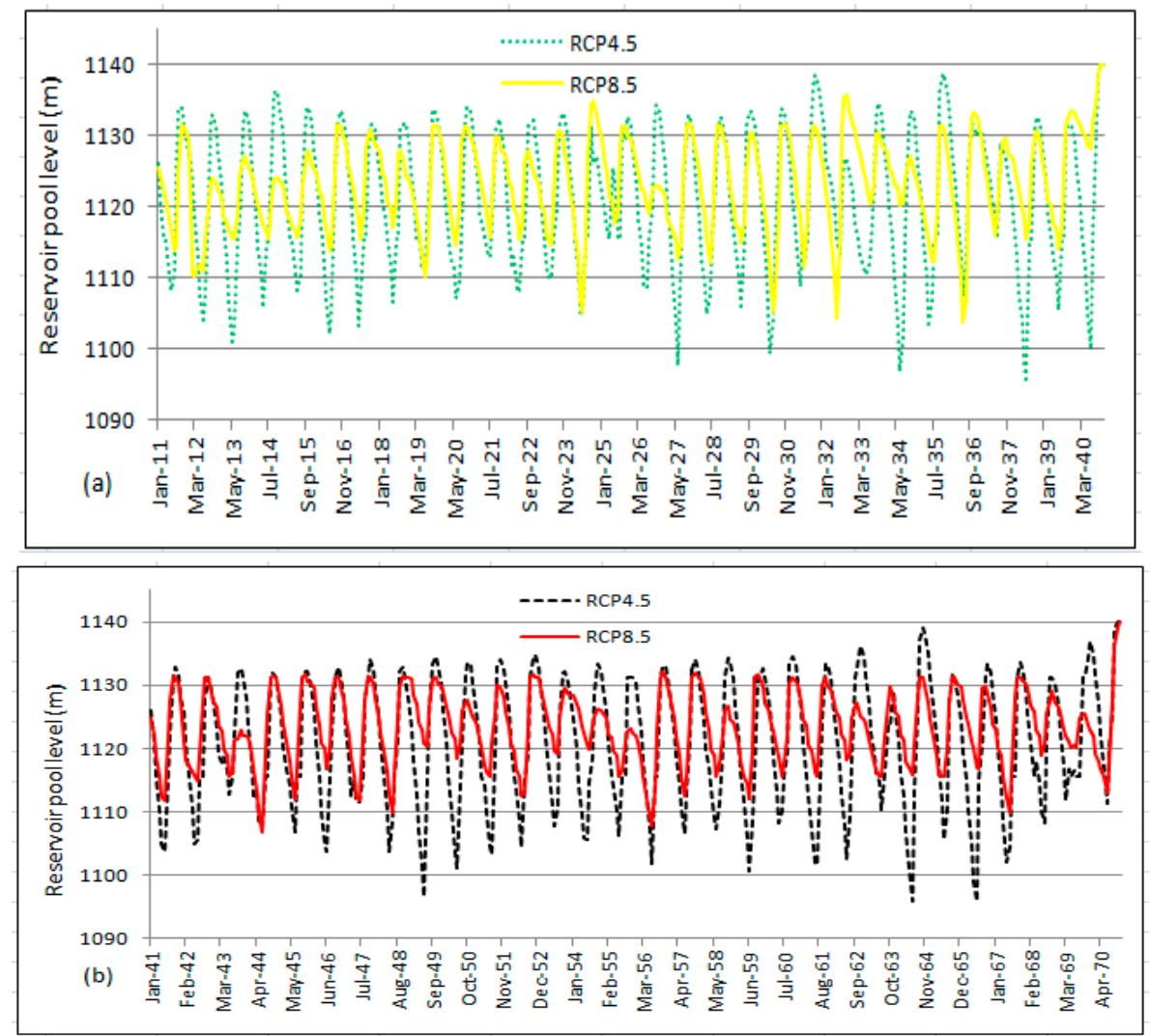

Figure 9. Cont. 


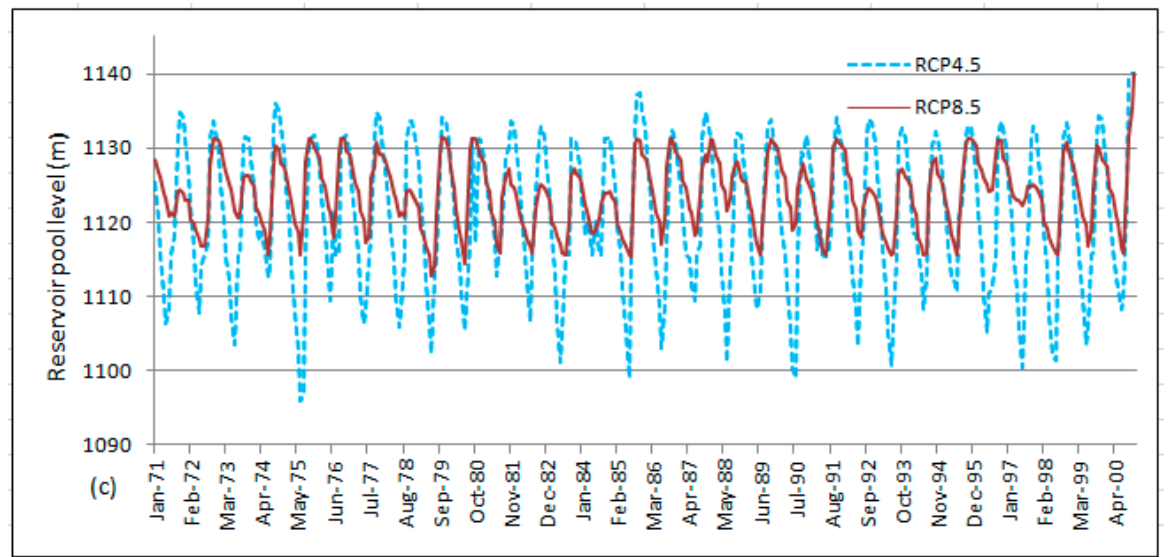

Figure 9. Monthly optimum pool level variations under RCP4.5 and RCP8.5 climate scenarios in three time periods: (a) 2020s; (b) 2050s; (c) 2080s.

There is no doubt that the hydropower system of Tekeze basin will be affected by climate change. With over all predicted increases in precipitation and streamflow, inflow to the reservoir anticipated to increase. Therefore, even though both RCP4.5 and RCP8.5 climate scenarios exhibited higher water inflow volume to Tekeze hydropower reservoir, this did not necessarily result in significantly more hydropower generation. Optimal operation of the reservoir using HEC-ResPRM considerably increases the power production by storing the higher inflow volume to inflow deficiency periods. Based on this research, the potential for hydropower production in the Tekeze hydropower reservoir is predicted to increase if appropriate reservoir operation techniques are used by operators and water managers to store and use the wet months flow to the dry months. Even if many optimization models and techniques have been developed in several fields of water resources system analysis such as hydropower reservoir operation around the world, the adaptation of such techniques and tools by water managers is slow. Researchers and scientists must accept the fact that the gap still exists between research studies and applications in practice. There need to be research on how to translate science to improve management operations of reservoirs for optimal results.

\section{Conclusions}

This study used a semi-distributed hydrological model (SWAT) and a reservoir optimization model (HEC-ResPRM) to evaluate the hydrological impacts of climate change on Tekeze hydropower reservoir operation in Tekeze basin part of Eastern Nile. We have evaluated climatic data (historical and future period) from the ensemble outputs of CORDEX-Africa RCMs under RCP4.5 and RCP8.5 climate scenarios for the periods of 2020s, 2050s, and 2080s. Calibrated SWAT model was used to generate climate change induced streamflow that was used as an input for optimal reservoir operation modeling. Analysis conducted on Tekeze hydropower reservoir inflows and outflow, reservoir storage volume and reservoir pool levels revealed the following:

1. This study found that the impact of climate change would increase in precipitation, temperature and streamflow in Tekeze basin under RCP4.5 and RCP8.5 climate scenarios over future periods which have an impact on current and future Tekeze hydropower reservoir operation.

2. Projected annual and inter-annual reservoir inflow showed increasing trend under both RCP4.5 and RCP8.5 climate scenarios.

3. HEC-ResPRM incorporates water storage, water surface elevation, release and power generation would provide better understanding of current and future conditions of Tekeze hydropower reservoir operation. 
4. Current optimized power storage and pool level show more optimal results than the current actual operation, so it is recommended to change the current operating policy to produce more power throughout the year.

5. The projected increase of reservoir inflow under an ensemble of CORDEX-Africa RCP4.5 and RCP8.5 future climate scenarios lead to optimized reservoir power storage, pool level (head) and release that greatly exceed those historically observed, indicating a shift in current water system behavior.

6. The study showed that climate change clearly affects future reservoir planning and management in Tekeze basin. Therefore, water resources planners, managers and operators should consider climate change impacts in the design, planning and management of reservoir systems.

7. In practice, many reservoir system operators and water managers feel more comfortable to use pre-defined rule curves and simulation results which are easy to understand and operate as most optimal operating rules developed by scientists using sophisticated optimization models and algorithms are mathematically more complex. The use of a combination of simulation and optimization models may solve this problem.

8. This study has not considered the changes in land use/land cover due to socio-economic development in the future. Coupling climate models with projected changes in land use associated with climate change impacts and effect of climate change adaptation on erosion and sediment yield which is necessary to evaluate projected changes in runoff associated with future Tekeze River basin development. Hence, further studies are recommended to quantify future change in streamflow and sedimentation load in Tekeze hydropower reservoir as well as its implication on future hydropower generation.

Acknowledgments: The research presented has been financially supported by the Ethiopian Government via Addis Ababa University (PhD studentship for the first author). The first author would like to give his thanks to Florida International University in assisting for the two months research visit. We acknowledge the data support of Ethiopian Ministry of Water, Irrigation and Electricity, National Meteorological Service Agency and Electric Power Corporation.

Author Contributions: Fikru Fentaw was responsible for this current research article in the framework of his PhD program and initially wrote the manuscript. Dereje Hailu, Agizew Nigussie, and Assefa M. Melesse directed the study by helping to interpret the results, particularly Assefa M. Melesse who contributed more on editing and organizing of this research article.

Conflicts of Interest: The authors declare no conflict of interest.

\section{References}

1. Zhou, Y.; Guo, S.; Duan, W.; Chen, H.; Liu, P. Dynamic control of flood limited water level for cascade reservoirs. J. Hydroelectr. Eng. 2015, 34, 23-30.

2. Yazdi, J.; Moridi, A. Interactive reservoir-watershed modeling framework for integrated water quality management. Water Resour. Manag. 2017, 31, 2105-2125. [CrossRef]

3. Birhanu, K.; Alamirew, T.; Dinka, M.O.; Ayalew, S.; Aklog, D. Optimizing reservoir operation policy using chance constraint nonlinear programming for Koga Irrigation Dam, Ethiopia. Water Resour. Manag. 2014, 28, 4957-4970. [CrossRef]

4. Rani, D.; Moreira, M.M. Simulation-optimization modeling: A survey and potential application in reservoir systems operation. Water Resour. Manag. 2010, 24, 1107-1138. [CrossRef]

5. David, S.; Randolph, B.; Upali, A. Water scarcity in the Twenty-first century. Int. J. Water Resour. Dev. 1999, 15, 29-42. [CrossRef]

6. Jury, W.A.; Henry, J.V.J. The emerging global water crisis: Managing scarcity and conflict between water users. Adv. Agron. 2007, 95, 1-76.

7. Rijsberman, G. Water scarcity: Fact or fiction? Agric. Water Manag. 2006, 80, 5-22. [CrossRef]

8. Larson, K.L.; Polsky, C.; Gober, P.; Chang, H.; Shandas, V. Vulnerability of water systems to the effects of climate change and urbanization: A comparison of Phoenix, Arizona and Portland, Oregon (USA). Environ. Manag. 2013, 52, 179-195. [CrossRef] [PubMed] 
9. Ghashghaie, M.; Marofi, S.; Marofi, H. Using system dynamics method to determine the effect of water demand priorities on downstream flow. Water Resour. Manag. 2014, 28. [CrossRef]

10. Guo, S.; Chen, J.; Li, Y.; Liu, P.; Li, T. Joint operation of the multi-reservoir system of the Three Gorges and the Qingiiang Cascade Reservoirs. Energies 2011, 4, 1036-1050. [CrossRef]

11. Zhou, Y.; Guo, S.; Liu, P.; Xu, C. Joint operation and dynamic control of flood limiting water levels for mixed cascade reservoir systems. J. Hydrol. 2014, 519, 248-257. [CrossRef]

12. Azizipour, M.; Ghalenoei, V.; Afshar, M.H.; Solis, S.S. Optimal operation of hydropower reservoir systems using weed optimization algorithm. Water Resour. Manag. 2016, 30, 3995-4009. [CrossRef]

13. He, Y.; Xu, Q.; Yang, S.; Liao, L. Reservoir flood control operation based on chaotic particle swarm optimization algorithm. Appl. Math. Model. 2014, 38, 4480-4492. [CrossRef]

14. Lu, B.; Li, K.; Zhang, H.; Wang, W.; Gu, H. Study on the optimal hydropower generation of Zhelin reservoir. J. Hydro-Environ. Res. 2013, 7, 270-278. [CrossRef]

15. Cheng, C.-T.; Wang, W.-C.; Xu, D.-M.; Chau, K.W. Optimizing hydropower reservoir operation using hybrid genetic algorithm and chaos. Water Resour. Manag. 2008, 22, 895-909. [CrossRef]

16. Yin, X.A.; Yang, Z.F. Development of a coupled reservoir operation and water diversion model: Balancing human and environmental flow requirements. Ecol. Model. 2011, 222, 224-231. [CrossRef]

17. Milly, P.; Betancourt, J.; Falkenmark, M.; Hirsch, R.M.; Kundzewicz, W.Z.; Lettenmaier, P.D.; Stouffer, R.J. Stationarity is dead: Whither water management? Science 2008, 319, 573-574. [CrossRef] [PubMed]

18. Stocker, D.; Qin, G.-K.; Plattner, L.V.; Allen, S.K. Technical summary. In Climate Change 2013: The Physical Science Basis. Contribution of Working Group I to the Fifth Assessment Report of the Intergovernmental Panel on Climate Change; Cambridge University Press: Cambridge, UK, 2013; pp. 31-116, ISBN 978-1-107-41532-4.

19. Huntington, T.G. Climate warming-induced intensification of the hydrologic cycle: An assessment of the published record and potential impacts on agriculture. In Advances in Agronomy; Sparks, D.L., Ed.; Academic Press: Cambridge, MA, USA, 2010; Volume 109, pp. 1-53.

20. Vicuña, S.; Garreaud, R.D.; McPhee, J. Climate change impacts on the hydrology of a snowmelt driven basin in semiarid Chile. Clim. Chang. 2011, 105, 469-488. [CrossRef]

21. Alazzy, A.; Lü, H.; Zhu, Y. Impact of climate change on evaluation of future water demand in the Euphrates and Aleppo basin, Syria. Proc. Int. Assoc. Hydrol. Sci. 2014, 364, 307-312. [CrossRef]

22. Zhang, C.; Zhu, X.; Fu, G.; Zhou, H.; Wang, H. The impacts of climate change on water diversion strategies for a water deficit reservoir. J. Hydroinform. 2014, 16, 872-889. [CrossRef]

23. Lumbroso, D.M.; Woolhouse, G.; Jones, L. A review of the consideration of climate change in the planning of hydropower schemes in sub-Saharan Africa. Clim. Chang. 2015, 133, 621-633. [CrossRef]

24. Lee, S.-Y.; Hamlet, A.F.; Grossman, E.E. Impacts of climate change on regulated streamflow, hydrologic extremes, hydropower production, and sediment discharge in the Skagit River Basin. Northwest Sci. 2016, 90, 23-43. [CrossRef]

25. Setegn, S.; Melesse, A.; Haiduk, A.; Webber, D.; Wang, X.; McClain, M. Modeling hydrological variability of fresh water resources in the Rio Cobre watershed, Jamaica. Catena 2014, 120, 81-90. [CrossRef]

26. Ehsani, N.; Vörösmarty, C.J.; Fekete, B.M.; Stakhiv, E.Z. Reservoir operations under climate change: Storage Capacity options to mitigate risk. J. Hydrol. 2017, 555, 435-446. [CrossRef]

27. Haile, A.T.; Akawka, A.L.; Berhanu, B.; Rientjes, T. Changes in water availability in the Upper Blue Nile Basin under the representative concentration pathways scenario. Hydrol. Sci. J. 2017, 62, 2139-2149. [CrossRef]

28. Zhu, X.; Zhang, C.; Qi, W.; Cai, W.; Zhao, X.; Wang, X. Multiple climate change scenarios and runoff response in Biliu River. Water 2018, 10, 126. [CrossRef]

29. Serdeczny, O.; Adams, S.; Baarsch, F.; Coumou, D.; Robinson, A.; Hare, W.; Schaeffer, M.; Perrette, M.; Reinhardt, J. Climate change impacts in Sub-Saharan Africa: From physical changes to their social repercussions. Reg. Environ. Chang. 2017, 17, 1585-1600. [CrossRef]

30. Conway, D.; Persechino, A.; Ardoin-Bardin, S.; Hamandawana, H.; Dieulin, C.; Mahé, G. Rainfall and water resources variability in Sub-Saharan Africa during the twentieth century. J. Hydrometeorol. 2009, 10, 41-59. [CrossRef]

31. Hales, S. Contribution of Working Group II to the Fourth Assessment Report of the Intergovernmental Panel on Climate Change; Climate Change 2007: Impacts, Adaptation and Vulnerability; Parry, M.L., Canziani, O.F., Palutikof, J.P., van der Linden, P.J., Hanson, C.E., Eds.; Cambridge University Press: Cambridge, UK, 2007. 
32. Nikulin, G.; Jones, C.; Giorgi, F.; Asrar, G.; Büchner, M.; Cerezo-Mota, R.; Christensen, O.B.; Déqué, M.; Fernandez, J.; Hänsler, A.; et al. Precipitation climatology in an ensemble of CORDEX-Africa regional climate simulations. J. Clim. 2012, 25, 6057-6078. [CrossRef]

33. Kim, U.; Kaluarachchi, J.J. Climate change impacts on water resources in the Upper Blue Nile River Basin, Ethiopia. JAWRA J. Am. Water Resour. Assoc. 2009, 45, 1361-1378. [CrossRef]

34. Beyene, T.; Lettenmaier, D.P.; Kabat, P. Hydrologic impacts of climate change on the Nile River Basin: implications of the 2007 IPCC scenarios. Clim. Chang. 2010, 100, 433-461. [CrossRef]

35. Yamba, F.D.; Walimwipi, H.; Jain, S.; Zhou, P.; Cuamba, B.; Mzezewa, C. Climate change/variability implications on hydroelectricity generation in the Zambezi River Basin. Mitig. Adapt. Strateg. Glob. Chang. 2011, 16, 617-628. [CrossRef]

36. Hamududu, B.H.; Killingtveit, $\AA$. Hydropower production in future climate scenarios; the case for the Zambezi River. Energies 2016, 9, 502. [CrossRef]

37. Abtew, W.; Melesse, A.M.; Dessalegne, T. Spatial, inter and intra-annual variability of the Upper Blue Nile Basin rainfall. Hydrol. Process. 2009, 23, 3075-3082. [CrossRef]

38. Mengistu, D.; Bewket, W.; Lal, R. Recent spatiotemporal temperature and rainfall variability and trends over the Upper Blue Nile River Basin, Ethiopia. Int. J. Climatol. 2014, 34, 2278-2292. [CrossRef]

39. Tarekegn, D.; Tadege, A. Assessing the Impact of Climate Change on the Water Resources of the Lake Tana Basin Using the WATBAL Model; CEEPA (the Centre for Environmental Economics and Policy in Africa): Pretoria, South Africa, 2006.

40. Melesse, A.M.; Loukas, A.G.; Senay, G.; Yitayew, M. Climate change, land-cover dynamics and ecohydrology of the Nile River Basin. Hydrol. Process. 2009, 23, 3651-3652. [CrossRef]

41. Setegn, S.G.; Rayner, D.; Melesse, A.M.; Dargahi, B.; Srinivasan, R. Impact of climate change on the hydroclimatology of Lake Tana Basin, Ethiopia. Water Resour. Res. 2011, 47, W04511. [CrossRef]

42. Jamali, S.; Abrishamchi, A.; Madani, K. Climate change and hydropower planning in the Middle East: implications for Iran's Karkheh hydropower systems. J. Energy Eng. 2013, 139, 153-160. [CrossRef]

43. Vonk, E.; Xu, Y.; Booij, M.; Zhang, X.; Augustijn, D.C.M. Adapting multireservoir operation to shifting patterns of water supply and demand. Water Resour. Manag. 2014, 28, 625-643. [CrossRef]

44. Wilby, R.L.; Harris, I. A framework for assessing uncertainties in climate change impacts: Low-flow scenarios for the River Thames, UK. Water Resour. Res. 2006, 42, W02419. [CrossRef]

45. Raje, D.; Mujumdar, P.P. Reservoir performance under uncertainty in hydrologic impacts of climate change. Adv. Water Resour. 2010, 33, 312-326. [CrossRef]

46. Haregeweyn, N.; Poesen, J.; Nyssen, J.; Gerared, G.; Verstraeten, G.; de Vente, J.; Deckers, L.; Moeversons, J.; Haile, M. Sediment yield variability in Northern Ethiopia: A quantitative analysis of its controlling factors. Catena 2008, 75, 65-76. [CrossRef]

47. Wolde, E. Identification and prioritization of sub watersheds for land and water management in Tekeze Dam watershed, Northern Ethiopia. Int. Soil Water Conserv. Res. 2016, 4, 30-38. [CrossRef]

48. Wurbs, R.A. Reservoir-system simulation and optimization models. J. Water Resour. Plan. Manag. 1993, 119, 455-472. [CrossRef]

49. Oliveira, R.; Loucks, D.P. Operating rules for multireservoir systems. Water Resour. Res. 1997, 33, 839-852. [CrossRef]

50. Labadie, J.W. Optimal operation of multireservoir systems: State-of-the-art review. J. Water Resour. Plan. Manag. 2004, 130, 93-111. [CrossRef]

51. Yeh, W.W.-G. Reservoir management and operations models: A state-of-the-art review. Water Resour. Res. 1985, 21, 1797-1818. [CrossRef]

52. Ayalew, L. The effect of seasonal rainfall on landslides in the highlands of Ethiopia. Bull. Eng. Geol. Environ. 1999, 58, 9-19. [CrossRef]

53. Van Vuuren, D.P.; Edmonds, J.; Kainuma, M.; Riahi, K.; Thomson, A.; Hibbard, K.; Hurtt, G.C.; Kram, T.; Krey, V.; Lamarque, J.-F.; et al. The representative concentration pathways: An overview. Clim. Chang. 2011, 109. [CrossRef]

54. Meinshausen, M.; Smith, S.J.; Calvin, K.; Daniel, J.S.; Kainuma, M.L.T.; Lamarque, J.-F.; Matsumoto, K.; Montzka, S.A.; Raper, S.C.B.; Riahi, K.; et al. The RCP greenhouse gas concentrations and their extensions from 1765 to 2300. Clim. Chang. 2011, 109, 213. [CrossRef] 
55. Taylor, K.E.; Stouffer, R.J.; Meehl, G.A. An overview of CMIP5 and the Experiment design. Bull. Am. Meteorol. Soc. 2011, 93, 485-498. [CrossRef]

56. Thomson, A.M.; Calvin, K.V.; Smith, S.J.; Kyle, P.G.; Volke, A.; Patel, P.; Delgado-Arias, S.; Bond-Lamberty, B.A.; Wise, M.A.; Clarke, L.E.; et al. RCP4.5: A pathway for stabilization of radiative forcing by 2100. Clim. Chang. 2011, 109, 77-94. [CrossRef]

57. Riahi, K.; Rao, S.; Krey, V.; Cho, C.; Chirkov, V.; Fischer, G.; Kindermann, G.; Nakicenovic, N.; Rafaj, P. RCP8.5-A scenario of comparatively high greenhouse gas emissions. Clim. Chang. 2011, 109, 33. [CrossRef]

58. Neitsch, S.; Arnold, J.; Kiniry, J.R.; Williams, J.R.; King, K. SWAT theoretical documentation. Grassland 2005, 494, 234-235.

59. Van Griensven, A.; Ndomba, P.; Yalew, S.; Kilonzo, F. Critical review of SWAT applications in the Upper Nile Basin countries. Hydrol. Earth Syst. Sci. 2012, 16, 3371-3381. [CrossRef]

60. Dessie, M.; Verhoest, N.E.C.; Admasu, T.; Pauwels, V.R.N.; Poesen, J.; Adgo, E.; Deckers, J.; Nyssen, J. Effects of the floodplain on river discharge into Lake Tana (Ethiopia). J. Hydrol. 2014, 519, 699-710. [CrossRef]

61. Faber, B.A.; Harou, J.J. Multiobjective optimization with HEC Res-PRM? Application to the Upper Mississippi Reservoir system. Oper. Reserv. Chang. Cond. 2006. [CrossRef]

62. Ostadrahimi, L.; Mariño, M.A.; Afshar, A. Multi-reservoir operation rules: Multi-swarm PSO-based optimization approach. Water Resour. Manag. 2012, 26, 407-427. [CrossRef]

(C) 2018 by the authors. Licensee MDPI, Basel, Switzerland. This article is an open access article distributed under the terms and conditions of the Creative Commons Attribution (CC BY) license (http:/ / creativecommons.org/licenses/by/4.0/). 